\title{
Biosorption of heavy metals from aqueous solutions by Saccharomyces Cerevisiae
}

\author{
Salah N. Farhan ${ }^{1} \cdot$ Anees A. Khadom ${ }^{1}$
}

Received: 19 November 2014/Accepted: 8 April 2015/Published online: 18 April 2015

(c) The Author(s) 2015. This article is published with open access at Springerlink.com

\begin{abstract}
The present work evaluates the performance of the yeast Saccharomyces Cerevisiae to remove heavy metals from aqueous solutions. The effect of $\mathrm{pH}$, temperature, initial concentration, contact time, and biosorbent dosage on biosorption capacity is studied. Experiment results show that metal uptake is a rapid process at $\mathrm{pH}$ values (5.0-6.0), and the order of accumulated metal ions is $\mathrm{Pb}>\mathrm{Zn}>\mathrm{Cr}>\mathrm{Co}>\mathrm{Cd}>\mathrm{Cu}$. The biosorption process obeys Freundlich and the Langmuir adsorption isotherms. The kinetics of metal ions biosorption could be described by Lagergren and Ho models. Nitric acid with low concentration of $0.05 \mathrm{~N}$ is effective in desorbing the biosorbed metal ions. Sodium hydroxide solution of $0.2 \mathrm{M}$ is effective in regenerating the yeast; the regenerated yeast could be used for at least six cycles of biosorption, without losing its metal removal capacity. Carboxyl, amine, and phosphate groups present in the yeast were found to be the main biosorption sites for metal ions.
\end{abstract}

Keywords Biosorption - Kinetics - Heavy metals · Yeast · Pretreatment

\section{Introduction}

In recent years, extensive attention has been paid on management of environmental pollution casual by hazardous materials such as heavy metals. Documentation of heavy metals in the water around industrial plants has been

Anees A. Khadom

aneesdr@gmail.com

1 Department of Chemical Engineering, College of

Engineering, Diyala University,

Baquba 32001, Diyala Governorate, Iraq a challenge for long time. Heavy metal pollution has become one of the most serious problems, and the presence of these metals even in traces is toxic and detrimental to both flora and fauna [1]. A number of methods have been developed for the removal of heavy metals from liquid wastes such as precipitation, evaporation, ion exchange, membrane processes, etc.; however, these methods have several disadvantages such as unpredictable metal ion removal, high regent requirement, generation of toxic sludge, etc. Biosorption is a process, which represents a biotechnology innovation as well as a cost-effective tool for removing heavy metals from aqueous solutions. In biosorption, either live or dead microorganisms or their derivatives are used, which complex metal ions through the functioning of ligands or functional groups located on the outer surface of the cell [2]. Microorganisms including bacteria, algae, fungi, and yeasts are found to be capable of efficiently accumulating heavy metals [3-5]. Saccharomyces cerevisiae was the first eukaryote to have its complete genome sequenced and this will undoubtedly lead to a new application [6]. Saccharomyces cerevisiae is easy to cultivate at large scale. The yeast can be easily grown using unsophisticated fermentation techniques and inexpensive growth media [7]. The biomass of $S$. cerevisiae can be obtained from various food and beverage industries. $S$. cerevisiae as a by-product is easier to get from fermentation industry, in comparison with other types of waste microbial biomass. Microorganisms used in enzymatic industry and pharmaceutical industry are usually involved in the secret of their products, which makes industries reluctant to supply the waste biomass. The supply of $S$. cerevisiae as waste residuals is basically stable. S. cerevisiae is generally regarded as safe. Therefore, biosorbents made from $S$. cerevisiae can be easily accepted by the public when applied practically, S. cerevisiae is an ideal 
model organism to identify the mechanism of biosorption in metal ion removal, especially to investigate the interactions of metal-microbe at molecular level. In fact, $S$. cerevisiae, as a model system in biology, has been explored fully in molecular biology [8]. Knowledge accumulated on the molecular biology of the yeast is very helpful to identify the molecular mechanism of biosorption in metal ion removal [9]. At the same time, S. cerevisiae can be easily manipulated genetically and morphologically, which is helpful to genetically modify the yeast more appropriate for various purposes of metal removal. The present work aims to study the removal of heavy metals from aqueous solution using low-cost, highly efficient regenerated biosorption technique. The potential of $S$. cerevisiae as a biosorbent material for the removal these metals was studied, effect of different treated methods on metal uptake of heavy ions at different $\mathrm{pH}$ values was studied also.

\section{Experimental work}

The chemicals used during the course of this work were all of analytical grade whenever available and were obtained from Sigma, Fisher, DIFCO or Mallinckrodt. Cleaning of glassware used in the experiments was done as follows: first, it was washed with detergent solution, rinsed with tap water, rinsed with $10 \%$ nitric acid, rinsed with tap water, and finally rinsed with distilled water to prevent metal binding to glasses. The cleaned glassware was dried prior to use in experiments. All metal solutions were prepared using metal acetate, metal sulphate, and metal chloride salts, and bi DDW water.

\section{Pretreatment method}

Raw yeast in batches of $5 \mathrm{~g}$ (dry weight) was pretreated; the yeast was slowly stirred in the chemical solution for a suitable period of time as shown in Table 1 . The yeast was washed with generous amounts of de ionized water and then dried in an oven at $60{ }^{\circ} \mathrm{C}$ for $6 \mathrm{~h}$. The feasibility of yeast cell was measured by taking $0.1 \mathrm{~mL}$ of high concentration yeast solution which diluted with ringar solution in a ratio of $1: 10$, then $0.1 \mathrm{~mL}$ from this solution was taken and mixed with $0.9 \mathrm{~mL}$ of methylen blue solution, then the colored yeasts were dead, and the others were raw [10].

\section{Batch experiments}

Once the yeast is introduced in a metal solution, biosorption of metal ion on yeast will take place. The heavy metal ion in solution will decrease until a certain value (equilibrium value) is reached. The time needed for the process is the equilibrium time. The effect of $\mathrm{pH}$ on the equilibrium time for biosorption of $\mathrm{Pb}, \mathrm{Cd}, \mathrm{Cr}, \mathrm{Cu}, \mathrm{Co}$, and $\mathrm{Zn}$ ions was studied using $\mathrm{pH}$ values of 2.0, 3.0, 4.0, 5.5, 6.0, and 8.0. These values were measured before and after tests, and no significant change in $\mathrm{pH}$ values was observed. After preparation of a metal solution with an initial concentration of approximately $10 \mathrm{mg} / \mathrm{L}$ with a $\mathrm{pH}$ that was adjusted

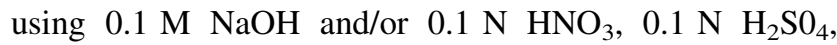
$0.1 \mathrm{~N} \mathrm{CH}_{3} \mathrm{COOH}$, and $0.1 \mathrm{~N} \mathrm{HCl}$, solution, a certain amount $(0.05-0.1 \mathrm{~g})$ of raw yeast without handling was added. In the meantime, a control without yeast was set up, while $\mathrm{pH}$ in the reaction mixture was not controlled. Samples were tested at 5, 15, 30, 50, 80, 120, 150, and $180 \mathrm{~min}$ and analyzed for residual metal ion concentration using Atomic Absorption (Scientific Atomic Absorptin Spectrophotometer Accu sys 211 Buck). These experiments were repeated and the mean values were used. Kinetic studies were performed for different initial metal ion concentrations $(10,20,40,60,80$, and $100 \mathrm{mg} / \mathrm{L})$ by suspending $0.1 \mathrm{~g}$ of sorbent in $100 \mathrm{~mL}$ of metal ion solution and the $\mathrm{pH}$ was adjusted to the desired value. The mixture was continuously stirred at $200 \mathrm{rpm}$. Samples were
Table 1 Saccharomyces cerevisiae pretreatment methods

\begin{tabular}{llll}
\hline Type & Solution $(75 \mathrm{~mL})$ & Duration (min) & Autoclave $^{\mathrm{a}}$ \\
\hline $\mathrm{M}_{0}$ & Raw yeast & Without handling & $\mathrm{x}$ \\
$\mathrm{M}_{1}$ & $0.1 \mathrm{~N} \mathrm{NaOH}$ & 120 & $\mathrm{x}$ \\
$\mathrm{M}_{2}$ & $0.1 \mathrm{~N} \mathrm{NaOH}$ & 120 & + \\
$\mathrm{M}_{3}$ & $0.1 \mathrm{~N} \mathrm{HCl}$ & 120 & $\mathrm{x}$ \\
$\mathrm{M}_{4}$ & $0.1 \mathrm{~N} \mathrm{HCl}$ & 120 & + \\
$\mathrm{M}_{5}$ & $0.2 \mathrm{~N} \mathrm{Na}_{2} \mathrm{CO}_{3}$ & 120 & $\mathrm{x}$ \\
$\mathrm{M}_{6}$ & $0.2 \mathrm{~N} \mathrm{Na} \mathrm{CO}_{3}$ & 120 & + \\
$\mathrm{M}_{7}$ & $\mathrm{H}_{2} \mathrm{O}$ & 360 & $\mathrm{x}$ \\
$\mathrm{M}_{8}$ & $125 \mathrm{~mL}$ of formaldehyde and $250 \mathrm{~mL}$ of formic acid & 120 & $\mathrm{X}$ \\
$\mathrm{M}_{9}$ & Immobilized yeast & - & \\
\hline
\end{tabular}

${ }^{a}$ Autoclaved for 30 min at $12 \mathrm{~L}^{\circ} \mathrm{C}(15)$ psi; (+) applied; (x) not applied 
withdrawn at pre-determined time intervals $(5,15,30,50$, $80,120,150$, and $180 \mathrm{~min}$ ) and analyzed for residual metal ion concentration.

\section{Results and discussion}

\section{Effect of environmental parameters}

\section{Effect of $p H$}

The $\mathrm{pH}$ of the solution is an important parameter for controlling the biosorption process. The effect of $\mathrm{pH}$ on the biosorption of $\mathrm{Pb}, \mathrm{Cd}, \mathrm{Cr}, \mathrm{Cu}, \mathrm{Co}$, and $\mathrm{Zn}$ ions was examined. The metallic ions biosorbed by each gram of biomass (q $\mathrm{mg}$ adsorbed/g biosorbent) and the biosorption efficiency were calculated by the following formula:

$q=\left(\frac{C_{\mathrm{i}}-C_{\mathrm{f}}}{m}\right) \times V$,

$E=\left(\frac{C_{\mathrm{i}}-C_{\mathrm{f}}}{C_{\mathrm{i}}}\right) \times 100$,

where $C_{\mathrm{i}}$ is the initial concentration and $C_{\mathrm{f}}$ is the final concentration of metal ions in $(\mathrm{mg} / \mathrm{L}), m$ is the mass of biosorbent $(\mathrm{g})$, and $V(\mathrm{~mL})$ is the volume of reaction mixture. Figure 1 shows these behaviors. At low pH, protons would compete with metals for the active sites responsible for the biosorption which would decrease the metal sorption. However, at an initial $\mathrm{pH}$ of 4.0 or less, lower biosorption was observed. It should be noted that at pH 2.0 the metals' biosorption has not been observed. The low biosorption capacity at $\mathrm{pH}$ values below 4.0 was attributed to hydrogen ions that compete with metal ions on the sorption sites. In other words, at lower $\mathrm{pH}$, due to

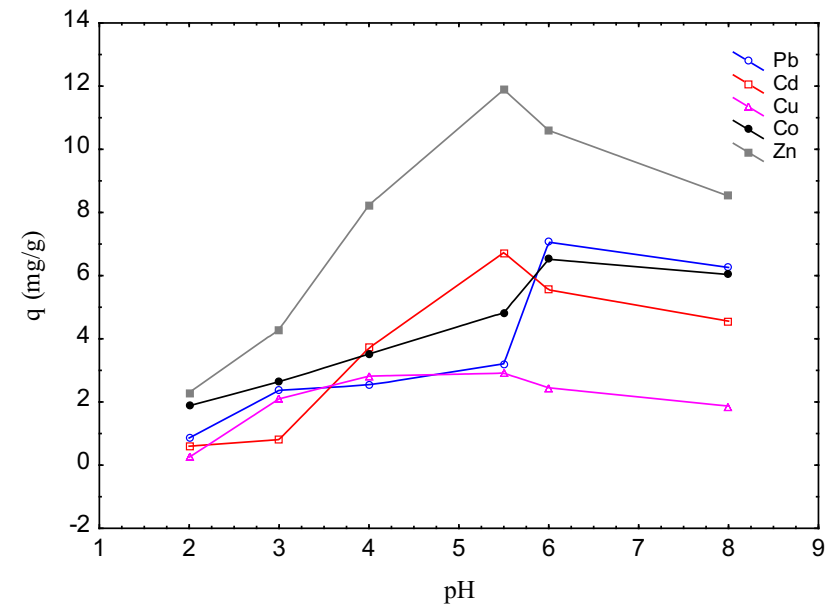

Fig. 1 Effect of $\mathrm{pH}$ on biosorption of metals ions. Reaction volume $=100 \mathrm{~mL}$, yeast weight $=0.1 \mathrm{~g}, T=25^{\circ} \mathrm{C}$ protonation of the binding sites resulting from a high concentration of protons, negative charge intensity on the sites is reduced, resulting in the reduction or even inhibition of the binding of metal ions. Similar findings were reported by other researchers $[11,12]$. The competition of the hydronium ions $\left[\mathrm{H}_{3} \mathrm{O}^{-}\right]$and metal ions for binding sites at low $\mathrm{pH}$ values makes ligands on the cell associate closely with the hydronium ions, but at high $\mathrm{pH}$ values, the hydronium ions are dissociated and the positively charged metal ions are associated with the free binding sites. Similar findings are reported by other researchers [13-15]. In fact, most microbial surfaces are negatively charged because of the ionization of functional groups, thus contributing to the metal binding $[16,17]$. At low $\mathrm{pH}$, some functional groups will be positively charged and may not interact with metal ions $[18,19]$.

\section{Effect of temperature}

Temperature has an influence on the biosorption of metal ions, but to a limited extent under a certain range of temperature. The increase of temperature indicating a decrease of sorption capacity and the maximum equilibrium uptake occurred at $27{ }^{\circ} \mathrm{C}$ as shown in Fig. 2. It is important to mention that the biosorption process is usually not operated at high temperature because it will increase the operational cost [1]. Since adsorption reactions are normally exothermic, biosorption capacities increase with decrease in temperature. The decrease in biosorption capacity between 27 and $62{ }^{\circ} \mathrm{C}$ may be due to the damage of active sites in the yeast. Many other researchers have also observed the same results $[20,21]$.

\section{Effect of time}

Figures 3 and 4 show the plots of the sorption capacities, (q) (mg/g), as a function of time at $27,37,52$, and $62{ }^{\circ} \mathrm{C}$. It is seen that the biosorption capacity increases with an

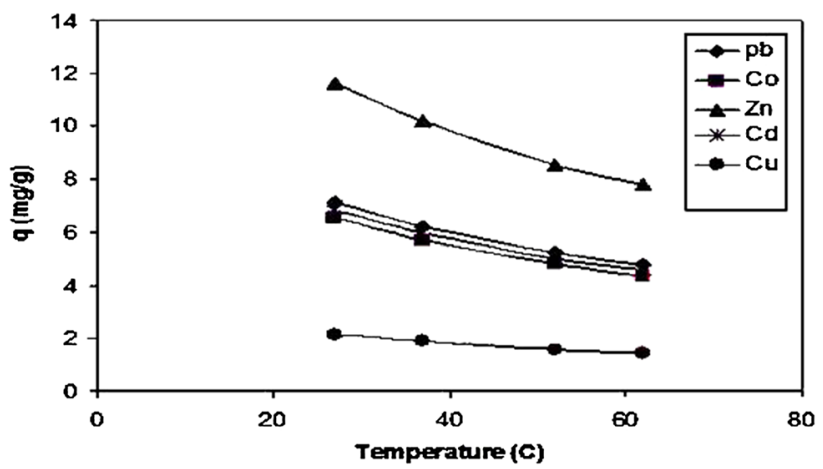

Fig. 2 Effect of temperature on biosorption of metal ions, reaction volume $=100 \mathrm{~mL}$, yeast weight $=0.1 \mathrm{~g}, C_{0}=10 \mathrm{mg} / \mathrm{L}$ 
increase in time at constant temperature. The amount of metal ion sorbed per unit mass of sorbent increases sharply up to 5 , and $30 \mathrm{~min}$ and increases thereafter, slowly reaching equilibrium. The short contact time of biosorbent with metal solution for biosorption suggests that adsorption onto the biosorbent surface is the main mechanism of uptake. Many other researchers also observed the same results $[11,22,23]$.

\section{Effect initial concentrations of metal ions}

These studies were carried out to determine the time required for biosorption of $\mathrm{Pb}, \mathrm{Cd}, \mathrm{Cu}, \mathrm{Co}$, and $\mathrm{Zn}$ on yeast to reach equilibrium. These experiments were conducted using $0.1 \mathrm{~g}$ yeast with $100 \mathrm{~mL}$ of metal solution at different initial concentrations. As seen in Fig. 5, biosorption has been observed to increase as initial concentration increases; this may be attributed to the active binding sites available for available sorbate ions [24]. Figure 5 shows that biosorption is very fast for all metal ions in the first $5 \mathrm{~min}$, while for the remaining time period, the metal concentrations in the liquid continued to diminish and reach an equilibrium concentration value. The faster first phase of metal biosorption may be attributed to the surface adsorption due to the action of ion exchange with the participation of some functional groups, while the second lower phase may represent diffusion of metal ions into the cell. Studies were carried out on $100 \mathrm{~mL}$ solution having concentration range $10-100 \mathrm{mg} / \mathrm{L}$ under best conditions of $\mathrm{pH}$ with yeast dosage of $0.1 \mathrm{~g} / \mathrm{L}$. At an initial concentration of $100 \mathrm{~g} / \mathrm{L}$ with the same dosage $(0.1 \mathrm{~g} / \mathrm{L})$, the residual concentration of lead approaches a level of $12.11 \mathrm{mg} / \mathrm{L}$

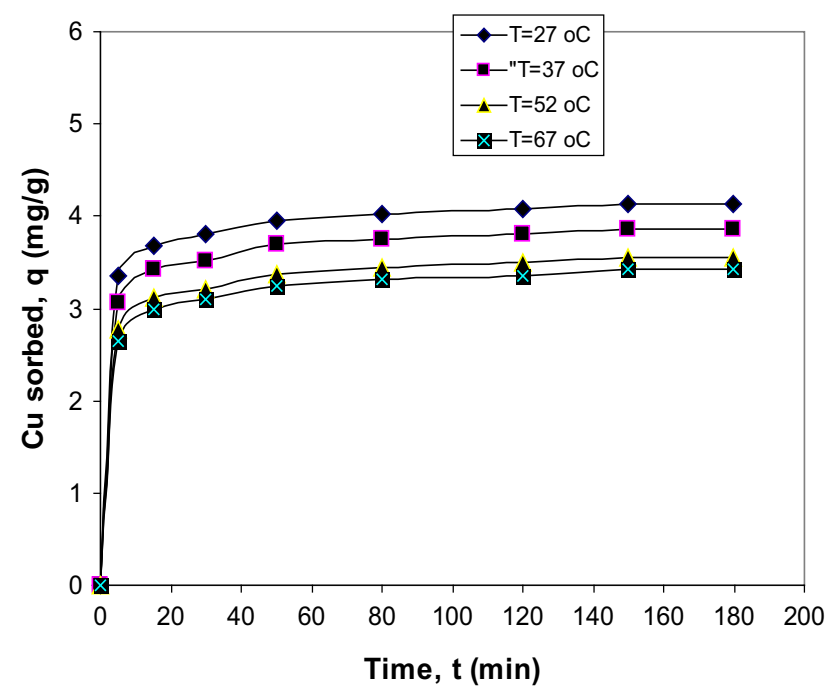

Fig. 3 Effect of temperature on biosorption of copper ions with time, reaction volume $=100 \mathrm{~mL}$, yeast weight $=0.1 \mathrm{~g}, C_{0}=10 \mathrm{mg} / \mathrm{L}$, $\mathrm{pH}=5.5$

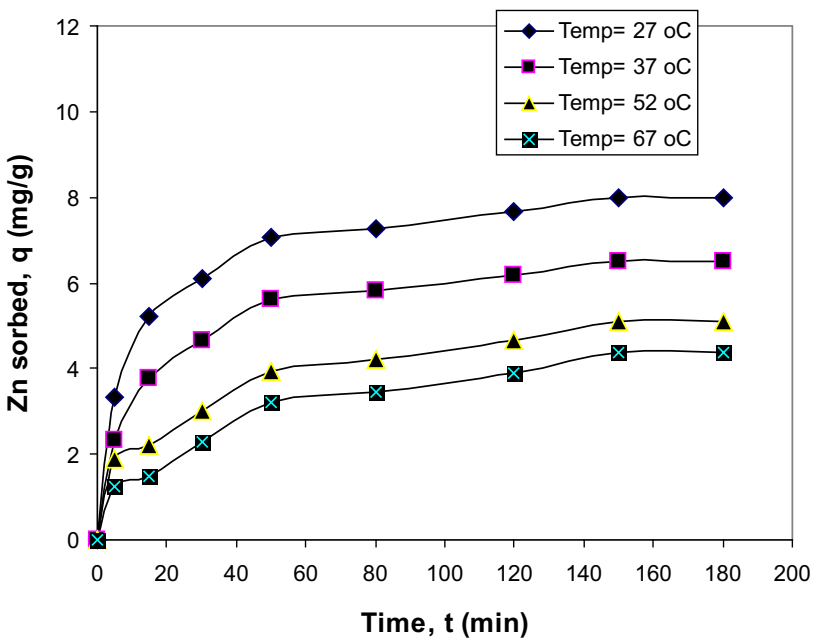

Fig. 4 Effect of temperature on biosorption of zinc ions with time, reaction volume $=100 \mathrm{~mL}$, yeast weight $=0.1 \mathrm{~g}, C_{0}=10 \mathrm{mg} / \mathrm{L}$, $\mathrm{pH}=5.5$

with an uptake of $86.14 \mathrm{mg} / \mathrm{g}$ while at lower concentrations of $8.99 \mathrm{mg} / \mathrm{L}$ the uptake decrease to level of $7.93 \mathrm{mg} / \mathrm{g}$ (Fig. 6). In case of other metals, the same results are obtained. Similar findings were reported by other researchers [25].

\section{Effect of yeast concentrations}

Sorption behavior of biosorbent at different dosages from 0.01 to $3 \mathrm{~g} / \mathrm{L}$ have been studied in $10-100 \mathrm{mg} / \mathrm{L}$ of solution under optimized condition of $\mathrm{pH}$ and contact time for respective metal. The effect of different initial concentrations of yeast on biosorption of the metal ions of $\mathrm{Pb}, \mathrm{Cd}$, $\mathrm{Cu}, \mathrm{Co}$, and $\mathrm{Zn}$ are shown in Fig. 7. All metal ions showed an increase in removal efficiency and decline in biosorption capacity on increasing of biomass from 0.01 to $0.1 \mathrm{~g}$ and this effect become less with further rise in biomass dose from 0.5 to $3 \mathrm{~g}$. More metal ions are removed at higher doses because of the availability of more active sites. The results obtained are in agreement with the work of Sudhir et al. [24], Chen and Wang [25], and Hany et al. [26].

\section{Adsorption, thermodynamics, and kinetics studies}

\section{Biosorption studies}

Biosorption equilibrium data give fundamental results to evaluate the applicability of biosorption processes as a unit operation, while the kinetic data provide the complete description of the transport mechanisms of adsorbate in adsorbent. Both the Langmuir and Freundlich models were used to describe adsorption isotherm. The Langmuir equation has the following form: 

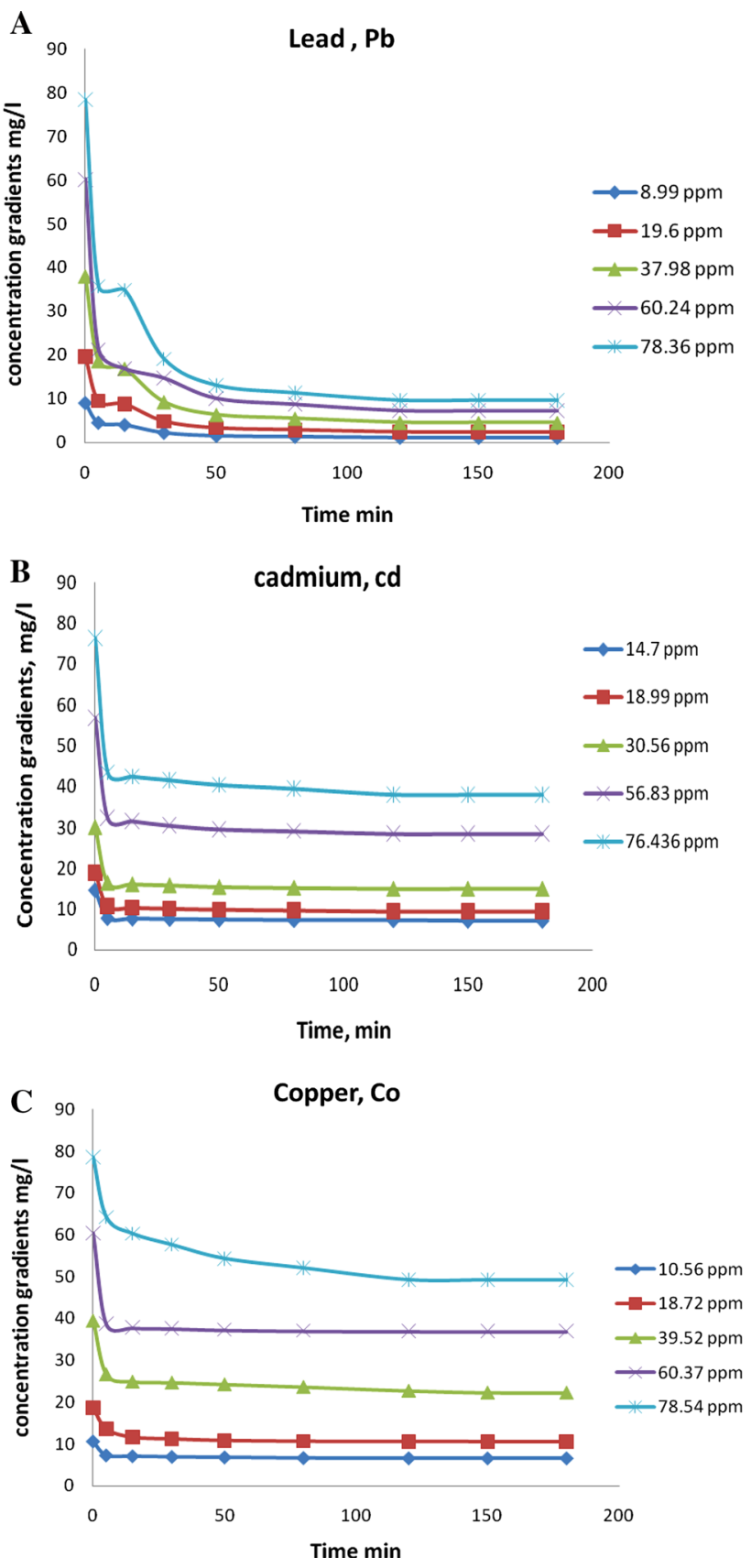

Fig. 5 a-c Effect of different initial concentrations on concentration gradient, reaction volume $=100 \mathrm{~mL}, \quad$ yeast weight $=0.1 \mathrm{~g}$, $T=27{ }^{\circ} \mathrm{C}$

$q_{\mathrm{e}}=q_{\mathrm{m}} \frac{K_{\mathrm{L}} C_{\mathrm{e}}}{1+K_{\mathrm{L}} C_{\mathrm{e}}}$,

where $q_{\mathrm{e}}$ is the amount adsorbed at time $t(\mathrm{mg} / \mathrm{g}), C_{\mathrm{e}}$ is the equilibrium concentration $(\mathrm{mg} / \mathrm{L}), K_{\mathrm{L}}$ is a constant related to the energy or net enthalpy of adsorption $(\mathrm{L} / \mathrm{mg})$, and $q_{\mathrm{m}}$ is the mass of adsorbed solute completely required to saturate a unit mass of adsorbent $(\mathrm{mg} / \mathrm{g})$. The Freundlich model is as follows:

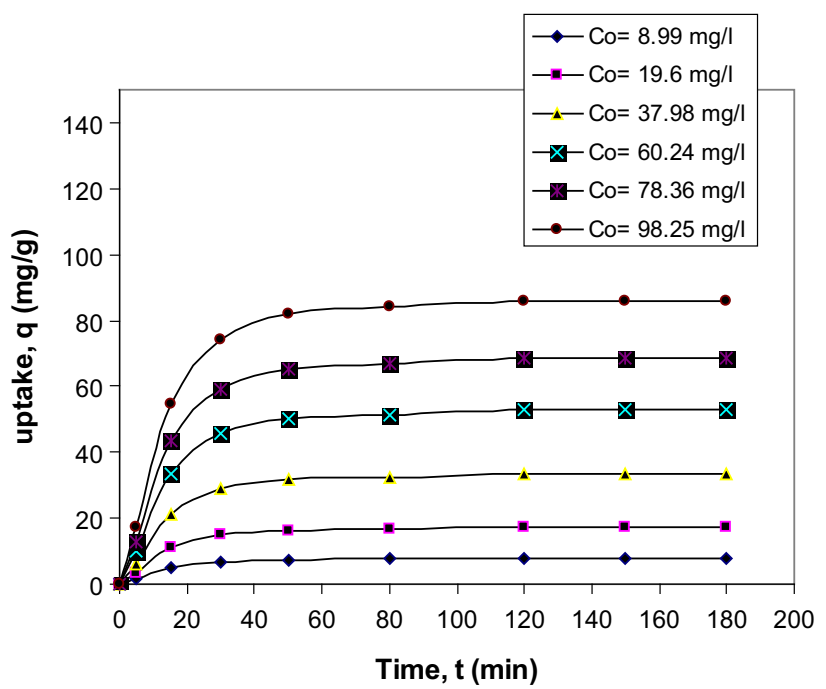

Fig. 6 Lead uptake with time at different initial concentrations, reaction volume $=100 \mathrm{~mL}$, yeast weight $=0.1 \mathrm{~g}, \mathrm{pH}=6.0$

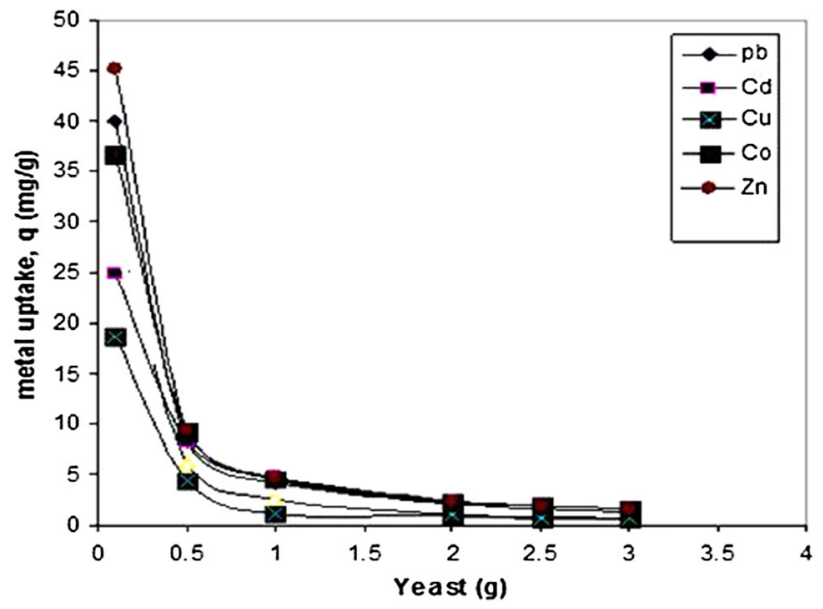

Fig. 7 Metal uptake at different yeast concentrations, reaction volume $=100 \mathrm{~mL}, \mathrm{pH}=5.5, T=27^{\circ} \mathrm{C}$

$q_{\mathrm{e}}=K_{\mathrm{F}} C_{\mathrm{e}}^{\frac{1}{n}}$

where $K_{\mathrm{F}}$ and $n$ are Freundlich equilibrium constants indicative of adsorption capacity and adsorption intensity, respectively. Nonlinear least squares regression analysis based on Levenberg-Marquardt estimation method can be used for estimation of coefficients of Eqs. 3 and 4 using STATISTICA Software Program, Version 7. Table 2 collects these constants. The correlation coefficients were high with two models. A high correlation coefficient indicated the adsorption of metal ions obey Langmuir isotherm model, suggesting a homogeneous adsorption within the adsorbent and formation of monolayer [27]. The obtained data also follow Freundlich isotherm model. In fact, the Freundlich isotherm model has the same meaning as the 
Table 2 Langmuir and Freundlich adsorption isotherm parameters of metal ions at different initial concentrations and optimum conditions

\begin{tabular}{|c|c|c|c|c|c|c|c|c|}
\hline \multirow[t]{2}{*}{ Metal ions } & \multirow[t]{2}{*}{$C_{0}(\mathrm{mg} / \mathrm{L})$} & \multicolumn{3}{|c|}{ Langmuir model } & \multirow[t]{2}{*}{$R^{2}$} & \multicolumn{2}{|c|}{ Freundlich model } & \multirow[t]{2}{*}{$R^{2}$} \\
\hline & & $q_{\mathrm{m}}$ & $K_{\mathrm{L}}$ & $R_{\mathrm{L}}$ & & $K_{\mathrm{F}}$ & $n$ & \\
\hline \multirow[t]{6}{*}{$\mathrm{Pb}$} & 98.25 & 108.69 & 9.2 & 0.0011 & 0.8605 & 53.11 & 32.05 & 0.8755 \\
\hline & 78.63 & 90.1 & 7.92 & 0.0016 & 0.8575 & 40.45 & 28.98 & 0.8714 \\
\hline & 60.24 & 60.24 & 18.44 & 0.0009 & 0.8362 & 39.81 & 53.47 & 0.8522 \\
\hline & 37.98 & 45.04 & 6.72 & 0.0039 & 0.8586 & 18.87 & 27.027 & 0.8833 \\
\hline & 19.6 & 22.32 & 7 & 0.0074 & 0.9391 & 9.42 & 26.738 & 0.9463 \\
\hline & 8.99 & 7.75 & 8.6 & 0.0127 & 0.9844 & 4.014 & 25.84 & 0.9821 \\
\hline \multirow[t]{6}{*}{$\mathrm{Cd}$} & 95.42 & 68.78 & 54.64 & 0.00019 & 0.9049 & 48.78 & 34.82 & 0.883 \\
\hline & 76.43 & 63.6 & 40.65 & 0.00032 & 0.9499 & 96.153 & 32.52 & 0.9202 \\
\hline & 56.83 & 43.17 & 30.03 & 0.00058 & 0.9534 & 104.16 & 24.47 & 0.9403 \\
\hline & 30.165 & 35.8714 & 15.723 & 0.002 & 0.9187 & 151.5 & 13.68 & 0.9047 \\
\hline & 18.99 & 33.3 & 10.07 & 0.0052 & 0.9157 & 108.69 & 8.21 & 0.9012 \\
\hline & 14.7 & 16.63 & 7.651 & 0.0088 & 0.8911 & 169.49 & 6.75 & 0.8711 \\
\hline \multirow[t]{6}{*}{$\mathrm{Cu}$} & 95.59 & 41.32 & 6.72 & 0.001554 & 0.7833 & 17.46 & 27.7 & 0.8298 \\
\hline & 78.63 & 43.66 & 4.77 & 0.002659 & 0.8297 & 14.78 & 22.72 & 0.8859 \\
\hline & 60.37 & 24.1 & 10.375 & 0.00016 & 0.7833 & 22.00 & 22.71 & 0.7915 \\
\hline & 39.52 & 18.93 & 20.3 & 0.001245 & 0.8954 & 13.07 & 58.82 & 0.9181 \\
\hline & 18.72 & 8.88 & 23.95 & 0.002225 & 0.897 & 6.41 & 66.22 & 0.9069 \\
\hline & 10.56 & 4.17 & 29.91 & 0.003156 & 0.9605 & 3.25 & 77.52 & 0.9646 \\
\hline \multirow[t]{6}{*}{ Co } & 94.62 & 72.99 & 13.7 & 0.0007 & 0.9118 & 42.8 & 41.49 & 0.9235 \\
\hline & 78.14 & 72.46 & 1.725 & 0.007 & 0.8526 & 32.7 & 29.32 & 0.8808 \\
\hline & 58.56 & 49.26 & 9.22 & 0.0018 & 0.8839 & 24.59 & 32.78 & 0.9232 \\
\hline & 38.42 & 47.21 & 5.16 & 0.0048 & 0.9112 & 15.502 & 24.75 & 0.9422 \\
\hline & 18.55 & 18.14 & 7.44 & 0.0075 & 0.944 & 7.89 & 27.47 & 0.9492 \\
\hline & 10.64 & 9.07 & 7.27 & 0.0127 & 0.9886 & 4.51 & 31.54 & 0.9739 \\
\hline \multirow[t]{6}{*}{$\mathrm{Zn}$} & 95.62 & 102.04 & 7 & 0.001492 & 0.8932 & 42.81 & 27.1 & 0.9212 \\
\hline & 78.31 & 83.33 & 7.05 & 0.001808 & 0.8933 & 35.05 & 27.02 & 0.9213 \\
\hline & 59.43 & 62.9 & 7.22 & 0.002325 & 0.8893 & 26.96 & 27.93 & 0.927 \\
\hline & 39.35 & 41.5 & 6.88 & 0.00368 & 0.9288 & 13.3 & 26.66 & 0.9508 \\
\hline & 19.23 & 20.24 & 6.86 & 0.007523 & 0.9337 & 8.42 & 26.52 & 0.9526 \\
\hline & 10.38 & 11.05 & 4.37 & 0.02157 & 0.9658 & 3.36 & 20 & 0.9696 \\
\hline
\end{tabular}

Langmuir isotherm model, and it assumes a heterogeneous energetic distribution of the active binding sites on the biomass as well as interactions between the adsorbed molecules [28]. Two isotherm models also in part explain in part why metal adsorption of biomass varied with the conditions.

\section{Thermodynamic studies}

Thermodynamic parameters such as free energy change $\left(\Delta G^{0}\right)$, enthalpy change $\left(\Delta H^{0}\right)$, and entropy change $\left(\Delta S^{0}\right)$ can be estimated using equilibrium constants changing with temperature. The free energy change is given by the following equation [29]:

$\Delta G^{0}=-R T \ln K_{\mathrm{D}}$
$K_{\mathrm{D}}=\frac{\text { Amount of metal in adsorbent }}{\text { Amount of metal in solution }}$,

where $K_{\mathrm{D}}$ is the distribution constant, $T$ is absolute temperature, and $R$ is gas constant. Free energy change $\left(\Delta G^{0}\right)$ varies with temperature according to

$\Delta G^{0}=\Delta H^{0}-T \Delta S^{0}$

Equations 5 and 6 were used to evaluate the values of free energy change $\left(\Delta G^{0}\right)$ and $K_{\mathrm{D}}$. Furthermore, Fig. 8 shows a graphical representation of Eq. 7 as $\Delta G^{0}$ against temperature. Table 3 collects the thermodynamic parameters for adsorption of heavy metals. The negative value for the Gibbs free energy for all six metals shows that the adsorption process is spontaneous, which is the usual case for many adsorption systems in solutions. The endothermic nature was also confirmed from the positive values of enthalpy change $\left(\Delta H^{0}\right)$. Table 3 also shows that 


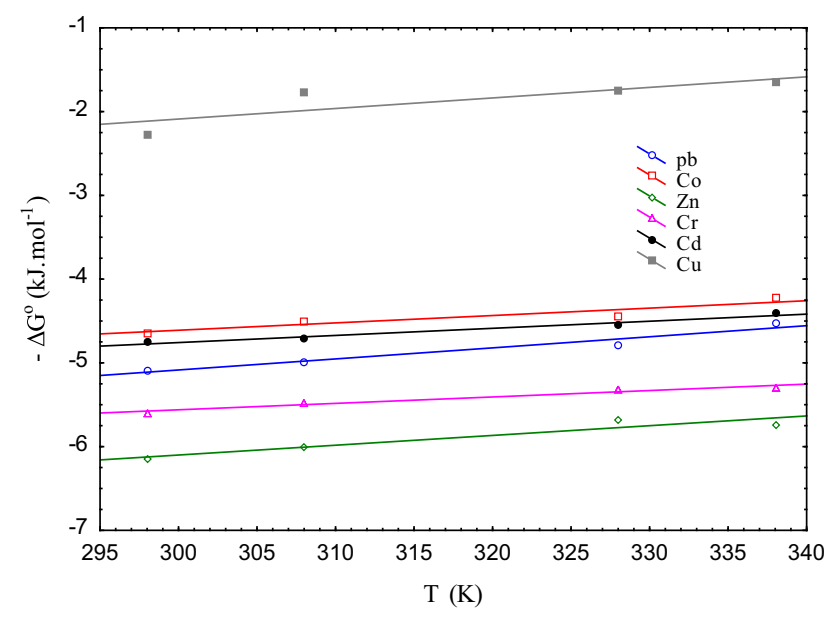

Fig. 8 Free adsorption energy against temperature, reaction volume $=100 \mathrm{~mL}$, yeast weight $=0.1 \mathrm{~g}$ and $\mathrm{pH}=5.5$

Table 3 Thermodynamic parameters for adsorption of heavy metals

\begin{tabular}{|c|c|c|c|c|c|}
\hline Metal & $T(\mathrm{~K})$ & $K_{\mathrm{D}}$ & $\Delta G^{0}(\mathrm{~kJ} / \mathrm{mol})$ & $\Delta H^{0}(\mathrm{~kJ} / \mathrm{mol})$ & $\Delta S^{0}(\mathrm{~kJ} / \mathrm{mol})$ \\
\hline \multirow[t]{4}{*}{$\mathrm{Pb}$} & 298 & 7.8 & -5.08 & -9.05 & 0.013 \\
\hline & 308 & 7 & -4.98 & & \\
\hline & 328 & 5.8 & -4.79 & & \\
\hline & 338 & 5 & -4.52 & & \\
\hline \multirow[t]{4}{*}{ Co } & 298 & 6.5 & -4.64 & -7.25 & 0.008 \\
\hline & 308 & 5.8 & -4.50 & & \\
\hline & 328 & 5.1 & -4.44 & & \\
\hline & 338 & 4.5 & -4.22 & & \\
\hline \multirow[t]{4}{*}{$\mathrm{Zn}$} & 298 & 12 & -6.15 & -9.61 & 0.011 \\
\hline & 308 & 10.4 & -5.99 & & \\
\hline & 328 & 8 & -5.67 & & \\
\hline & 338 & 7.7 & -5.74 & & \\
\hline \multirow[t]{4}{*}{$\mathrm{Cr}$} & 298 & 5.1 & -3.91 & -7.55 & 0.007 \\
\hline & 308 & 8.5 & -5.48 & & \\
\hline & 328 & 7 & -5.31 & & \\
\hline & 338 & 6.6 & -5.32 & & \\
\hline \multirow[t]{4}{*}{$\mathrm{Cd}$} & 298 & 6.8 & -4.74 & -7.32 & 0.008 \\
\hline & 308 & 6.3 & -4.71 & & \\
\hline & 328 & 5.3 & -4.54 & & \\
\hline & 338 & 4.8 & -4.41 & & \\
\hline \multirow[t]{4}{*}{$\mathrm{Cu}$} & 298 & 2.5 & -2.27 & -5.87 & 0.012 \\
\hline & 308 & 2 & -1.77 & & \\
\hline & 328 & 1.9 & -1.75 & & \\
\hline & 338 & 1.8 & -1.65 & & \\
\hline
\end{tabular}

the $\Delta S$ values were positive (i.e., that entropy increases as a result of adsorption). This occurs as a result of redistribution of energy between the adsorbate and the adsorbent. Before adsorption occurs, the heavy metal ions near the surface of the adsorbent will be more ordered than in the subsequent adsorbed state and the ratio of free heavy metal ions to ions interacting with the adsorbent will be higher than in the adsorbed state. As a result, the distribution of rotational and translational energy among a small number of molecules will increase with increasing adsorption by producing a positive value of $\Delta S$ and randomness will increase at the solid-solution interface during the process of adsorption [30].

\section{Kinetics studies}

The Lagergren first-order reaction rate model (pseudo-first order adsorption kinetics, Eq. 8) and Ho's second-order reaction rate model (pseudo-second order adsorption kinetics, Eq. 9) were used in describing the adsorption kinetics of heavy metals onto biomass $[31,32]$.

$\log \left(q_{\mathrm{e}}-q_{t}\right)=\log q_{\mathrm{e}}-\frac{K_{1}}{2.303} t$

$\frac{t}{q_{t}}=\frac{1}{K_{\mathrm{h}} q_{\mathrm{e}}^{2}}+\frac{1}{q_{\mathrm{e}}} t$.

where $K_{1}$ and $K_{\mathrm{h}}$ are the equilibrium rate constant of pseudo-first and second order adsorption kinetics, $q_{t}$ the amount of adsorbate on adsorbent at time $t(\mathrm{mg} / \mathrm{g})$, and $q_{\mathrm{e}}$ the equilibrium uptake $(\mathrm{mg} / \mathrm{g})$. Equation 8 can be drawn as $\log \left(q_{\mathrm{e}}-q_{\mathrm{t}}\right)$ against $t$, while Eq. 9 drawn as $t / q_{\mathrm{t}}$ against $t$. Slope and intercept of these equations give the kinetic parameters. These parameters are listed in Table 4. Both models represent the adsorption data with high correlation coefficients. Correlation coefficients of Ho's model were higher than Lagergren model. This suggests that the adsorption of heavy metals follow the second-order kinetic model. Figure 9 shows the predicted biosorption capacity of lead compared with the computed ones by Lagergren and Ho's models. It can be noted there are three stages of the adsorption kinetics. The initial process of external mass transfer was fast and confined to the first few minutes and is termed as first stage of sorption. The second and third stages of sorption were found to be clearly separated by a plateau depending on the concentration or availability of metal ions in the solutions for sorption. On the other hand, the results obtained by Ho's model are nearest to experimental data. The change in the metal concentration with respect to time for the first stage of sorption may be related to the liquid-solid mass transfer coefficient [32]. All other five metals behave in similar way. At lower concentration, the error between experimental and modeled data is smaller than that of higher concentration. On comparing the pseudo-first order and the pseudo-second order adsorption rate constants at different initial metal concentrations, it is seen that the second-order model provides best correlation of the data. The standard deviation is obtained through the following equation: 
Table 4 Lagergren and Ho's constants

\begin{tabular}{|c|c|c|c|c|c|c|c|}
\hline \multirow[t]{2}{*}{ Metal } & \multirow{2}{*}{$\begin{array}{l}\text { Concentration } \\
(\mathrm{mg} / \mathrm{L})\end{array}$} & \multicolumn{3}{|c|}{ Lagergren parameters } & \multicolumn{3}{|c|}{ Ho's parameters } \\
\hline & & $q_{\mathrm{e}}(\mathrm{mg} / \mathrm{g})$ & $K_{1}(/ \mathrm{min})$ & $R^{2}$ & $q_{\mathrm{e}}(\mathrm{mg} / \mathrm{g})$ & $K_{\mathrm{h}}(\mathrm{g} / \mathrm{mg} \min )$ & $R^{2}$ \\
\hline \multirow[t]{6}{*}{$\mathrm{Pb}$} & 98.25 & 103.99 & 0.0085 & 0.9472 & 80 & 0.01 & 0.9875 \\
\hline & 78.63 & 86.49 & 0.00812 & 0.9237 & 67 & 0.022 & 0.9833 \\
\hline & 60.24 & 56.68 & 0.0098 & 0.8853 & 31.12 & 0.035 & 0.9746 \\
\hline & 37.98 & 44.01 & 0.0053 & 0.9039 & 28.21 & 0.064 & 0.9781 \\
\hline & 19.6 & 24.787 & 0.0052 & 0.9101 & 18.08 & 0.08 & 0.9893 \\
\hline & 8.99 & 12.45 & 0.0083 & 0.9373 & 10.1 & 0.11 & 0.9851 \\
\hline \multirow[t]{6}{*}{$\mathrm{Cd}$} & 95.42 & 51.28 & 0.21 & 0.9649 & 50.06 & 0.028 & 0.9731 \\
\hline & 76.43 & 37.42 & 0.32 & 0.9416 & 38.256 & 0.036 & 0.9741 \\
\hline & 56.38 & 27.63 & 0.27 & 0.9152 & 24.746 & 0.058 & 0.9711 \\
\hline & 30.165 & 14.35 & 0.62 & 0.9112 & 13.114 & 0.108 & 0.973 \\
\hline & 18.99 & 9.24 & 0.45 & 0.9294 & 9.3686 & 0.1856 & 0.9759 \\
\hline & 14.7 & 7.035 & 0.185 & 0.9767 & 6.8048 & 0.187 & 0.9821 \\
\hline \multirow[t]{6}{*}{$\mathrm{Cr}$} & 60.43 & 52.63 & 0.016 & 0.9429 & 53.06 & 0.018 & 0.9731 \\
\hline & 52.6 & 44 & 0.018 & 0.9455 & 46.34 & 0.036 & 0.9741 \\
\hline & 44.32 & 37 & 0.018 & 0.9453 & 39.346 & 0.058 & 0.9711 \\
\hline & 28.32 & 25.49 & 0.023 & 0.9358 & 25.87 & 0.108 & 0.973 \\
\hline & 14.7 & 13 & 0.02 & 0.925 & 13.1 & 0.1856 & 0.9759 \\
\hline & 12.11 & 11.23 & $9.2 \times 10^{-4}$ & 0.9565 & 11.05 & 0.187 & 0.9821 \\
\hline \multirow[t]{6}{*}{$\mathrm{Cu}$} & 95.59 & 35.95 & 0.13 & 0.9418 & 31.41 & 0.48 & 0.9939 \\
\hline & 78.62 & 28.13 & 0.1103 & 0.9382 & 29.78 & 0.321 & 0.9937 \\
\hline & 60.37 & 23.63 & 0.018 & 0.8292 & 25.12 & 0.625 & 0.9989 \\
\hline & 39.52 & 15.99 & 0.148 & 0.9664 & 18.53 & 0.37 & 0.9988 \\
\hline & 18.72 & 8.07 & 0.111 & 0.9432 & 8.14 & 0.54 & 0.9994 \\
\hline & 10.56 & 4.13 & 0.0573 & 0.9544 & 4.08 & 1.17 & 0.9986 \\
\hline \multirow[t]{6}{*}{ Co } & 94.62 & 68.78 & 0.012 & 0.933 & 62.56 & 0.011 & 0.9776 \\
\hline & 78.14 & 68.31 & 0.00811 & 0.8998 & 54.23 & 0.0252 & 0.9777 \\
\hline & 58.56 & 46.88 & 0.0098 & 0.9524 & 40.34 & 0.0335 & 0.9828 \\
\hline & 38.42 & 45.77 & 0.0053 & 0.9603 & 29.077 & 0.062 & 0.9874 \\
\hline & 18.55 & 21.52 & 0.0051 & 0.9101 & 13.89 & 0.081 & 0.9842 \\
\hline & 10.64 & 14.421 & 0.0082 & 0.9373 & 12.54 & 0.135 & 0.9913 \\
\hline \multirow[t]{6}{*}{$\mathrm{Zn}$} & 95.62 & 98.12 & 0.005 & 0.9729 & 78.942 & 0.011 & 0.9534 \\
\hline & 78.31 & 80.02 & 0.0052 & 0.9505 & 62.38 & 0.022 & 0.9453 \\
\hline & 59.43 & 60.35 & 0.0052 & 0.9522 & 46.45 & 0.036 & 0.9765 \\
\hline & 39.35 & 39.87 & 0.00552 & 0.9653 & 23.08 & 0.065 & 0.9786 \\
\hline & 19.23 & 16.94 & 0.0052 & 0.9556 & 16.32 & 0.082 & 0.9856 \\
\hline & 10.38 & 10.76 & 0.0062 & 0.9404 & 14.22 & 0.44 & 0.9865 \\
\hline
\end{tabular}

Elution of biosorbed metal ions

where $q_{\mathrm{e}}^{\exp }$ and $q_{\mathrm{e}}^{\mathrm{cal}}$ are the experimental and calculated equilibrium uptake $(\mathrm{mg} / \mathrm{g})$, and $\mathrm{n}$ is number of values. Table 5 shows the standard deviation between two models and experimental data for the six metals. It can be noted that the results obtained by Ho's model are nearest to experimental data.
Various elutions were used to desorb the metal ions loaded on immobilized yeast. Table 6 shows the elution of biosorbed metals by various reagents. It is clear that $\mathrm{HNO}_{3}$ proved to be a more effective elutant than $\mathrm{CaCl}_{2}$ and distilled water. Bruno et al. [33] showed that more than $95 \%$ of lead could be desorbed from nonliving Sargassam sp. with the use of mineral acids. The mineral acids are proton 


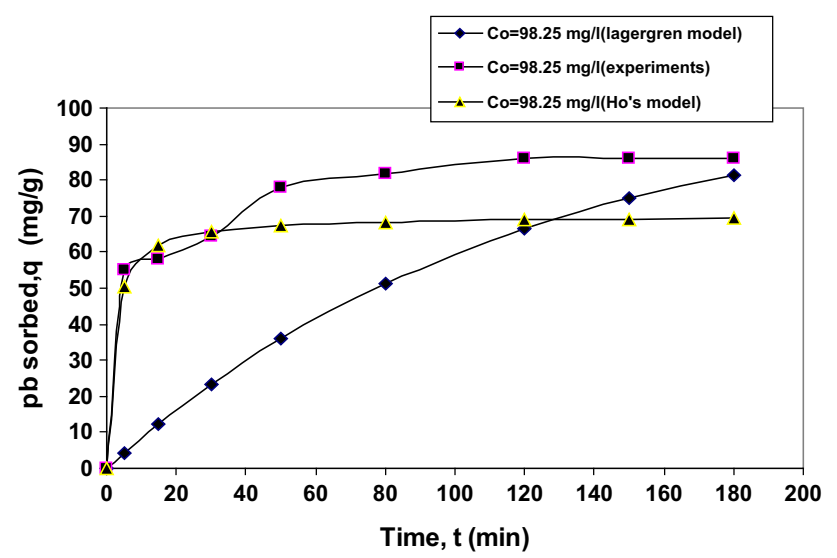

Fig. 9 Lagergren and Ho's models with experimental data of lead at $C_{0}=98.25 \mathrm{mg} / \mathrm{L}$

Table 5 Standard deviation of Lagergren and Ho's models for metals at $(95-100) \mathrm{mg} / \mathrm{L}$

\begin{tabular}{lll}
\hline Ho's model & Lagergren model & Metal \\
\hline 12.207 & 34.55 & $\mathrm{~Pb}$ \\
9.425 & 8.738 & $\mathrm{Cd}$ \\
2.148 & 26.036 & $\mathrm{Cr}$ \\
3.94 & 7.91 & $\mathrm{Cu}$ \\
8.544 & 23.45 & $\mathrm{Co}$ \\
15.736 & 26.76 & $\mathrm{Zn}$ \\
\hline
\end{tabular}

Table 6 Elution of biosorbed metals by various reagents

\begin{tabular}{lcccccc}
\hline Chemical reagent & \multicolumn{7}{c}{ \%ecovery of metals } \\
\cline { 2 - 7 } & $\mathrm{Pb}$ & $\mathrm{Cd}$ & $\mathrm{Cr}$ & $\mathrm{Cu}$ & $\mathrm{Co}$ & $\mathrm{Zn}$ \\
\hline Distilled water & 1.6 & 2.95 & 2.87 & 2.94 & 2.11 & 2.45 \\
$0.05 \mathrm{~N} \mathrm{HNO}_{3}$ & 96 & 94 & 93 & 92 & 91 & 91 \\
$\mathrm{CaCl}_{2}$ & 48 & 76 & 66 & 59 & 61 & 58 \\
\hline
\end{tabular}

exchange agents. $\mathrm{HNO}_{3}$ was able to effectively elute biosorbed metal ions from A. niger [13].

\section{Regeneration and reuse of immobilized yeast}

Biosorption capability of yeast and its reuse will decide its potential as a biosorbent in application. After biosorption of a metal ion, immobilized yeast is desorbed using $\mathrm{HNO}_{3}$ and then regenerated by washing with deionized water and $\mathrm{NaOH}$ solution. Immobilized yeast is used in batch experiments for 5 or 6 cycles of biosorption-elution-regeneration to investigate the potential of beads in retaining metal ions. The $\mathrm{pH}$ of $6-6.5$ was adjusted to minimize the effect of remaining $\mathrm{H}^{+}$. Table 7 shows the reuse of immobilized yeast in the biosorption of the six metals. Table 7 shows that the beads are still able to adsorb metal ions. The big variation in biosorption capacity values from cycle to cycle should be attributed to two factors, i.e. the uneven particle sizes of bead samples and the difference in final $\mathrm{pH}$ in the mixtures.

\section{Biosorption of heavy metals on raw and pretreated yeast}

The raw yeast in batches of $5 \mathrm{~g}$ (dry weight) was pretreated in seven ways listed in Table 1 . In each pretreatment, the yeast was treated as mentioned in Sect. 2.1. In type 9 the mixture were put in shaker for $2 \mathrm{~h}$ at $200 \mathrm{rpm}$ and then washed by deionized distilled water and $2 \%$ sodium bicarbonate. The viability of yeast cell was measured by taking $0.1 \mathrm{~mL}$ of high-concentration mixed yeast solution then diluted with ringar solution in a ratio of 1:10 then $0.1 \mathrm{~mL}$ from this solution was taken and mixed with $0.9 \mathrm{~mL}$ of methylen blue solution, then the colored yeasts were dead, and the others were raw [10]. Figure 10 shows the effect of pretreated yeast as compared with raw one for different metals. As shown in Fig. 10, lead increases depending on pretreatment method in comparison with biosorption using raw yeast. Pretreatment using $0.1 \mathrm{~N} \mathrm{HCl}$ increases biosorption capacity of lead from (6.00 to 11.63 , 7.44 to 11.91 , and from 7.49 to $12.44 \mathrm{mg} / \mathrm{g}$ ) at $\mathrm{pH} 4,5$, and 6 , respectively. Using $0.1 \mathrm{~N} \mathrm{HCl}$ with autoclaving gives results as $(6.00-2.97,7.44-12.93$, and $7.49-13.20 \mathrm{mg} / \mathrm{g})$. The reduction of biosorption capacity in comparison with raw yeast may be attributed to the loss of intracellular uptake or loss of amino functional groups on the yeast surface through the non-enzymic browning reaction at low $\mathrm{pH}$. Acid pretreatment of yeast significantly decreases biosorption of heavy metals. However, Huang and Huang [34] reported that acid pretreatment can strongly enhance the adsorption capacity of $A$. oryzae mycelia. Furthermore, they noted that raw biomass after acid pretreatment was directly used in biosorption of heavy metals instead of being autoclaved and dried. In this study, the $\mathrm{H}^{+}$ions

Table 7 Reuse of immobilized yeast in biosorption of lead, yeast dose $=0.05 \mathrm{~g}$, volume of metal solution $=75 \mathrm{~mL}$, volume of eluting agent $=25 \mathrm{~mL}, \mathrm{Co}=10.56 \mathrm{mg} / \mathrm{L}, \mathrm{pH}=6.5$

\begin{tabular}{lll}
\hline Cycle & \multicolumn{2}{l}{ Lead concentration in the solution after biosorption $(\mathrm{mg} / \mathrm{L})$} \\
\cline { 2 - 3 } & Eluting agent & $0.05 \mathrm{~N} \mathrm{HNO}_{3}$ \\
\cline { 2 - 3 } & Distilled water & 1.1864 \\
1 & 3.55 & 3.34 \\
2 & 3.24 & 2.87 \\
3 & 2.86 & 3.23 \\
4 & 3.29 & 4.12 \\
5 & 3.46 & 4.67 \\
6 & 3.88 & \\
\hline
\end{tabular}



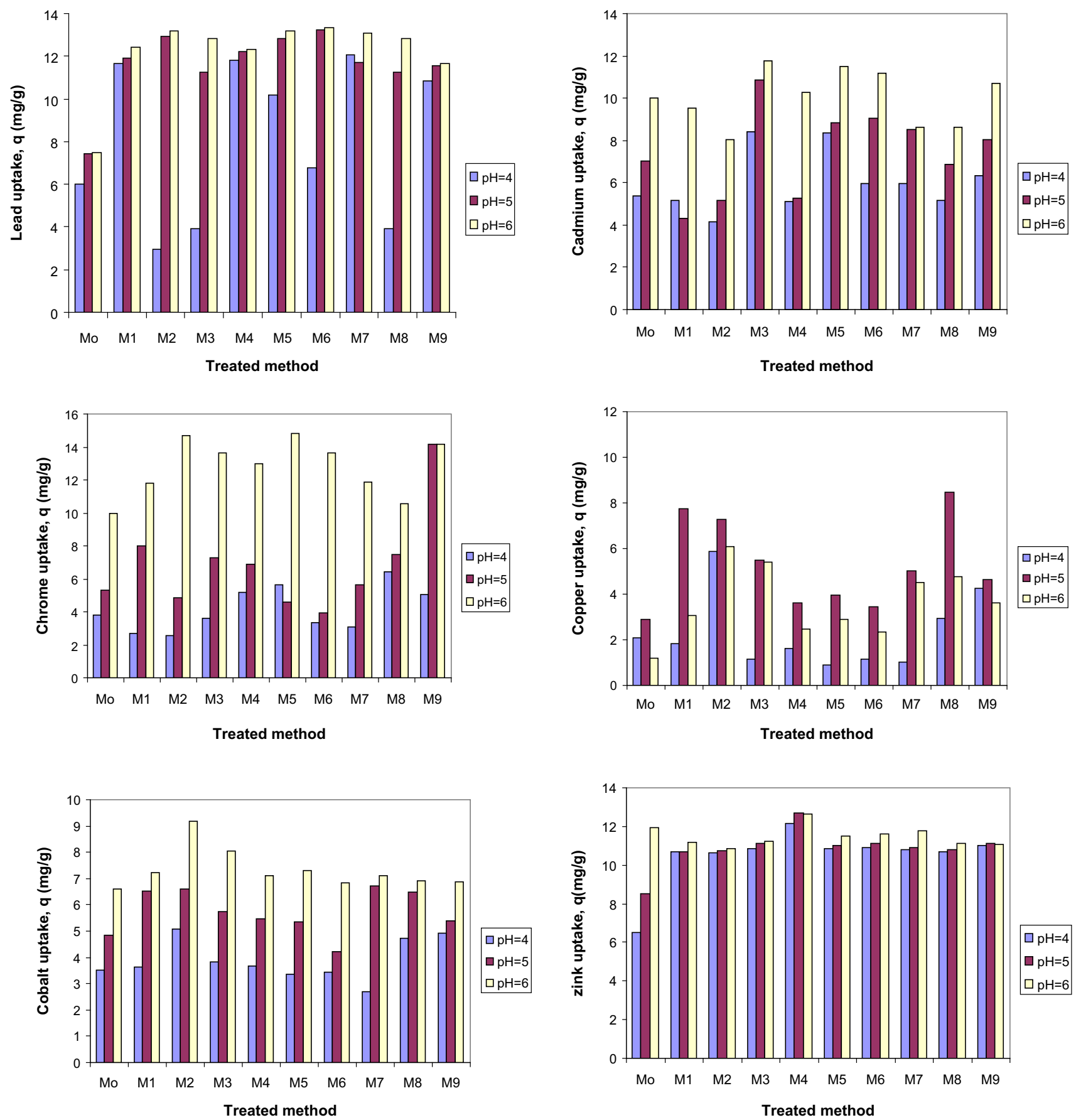

Fig. 10 Effect of different treated methods on metal uptake of heavy ions at different $\mathrm{pH}$ values, $0.05 \mathrm{~g}$ yeast, $\mathrm{v}=75 \mathrm{~mL}, \mathrm{M}_{0}=$ raw yeast, $\mathrm{M}_{1}=0.1 \mathrm{~N} \mathrm{HCl}, \mathrm{M}_{2}=0.1 \mathrm{~N} \mathrm{HCl}+$ autoclave, $\mathrm{M}_{3}=0.1 \mathrm{~N}$

bound to the biomass after acid treatment may be responsible for the reduction in sorption of heavy metals. The polymeric structure of biomass surface exhibits a negative charge due to the ionization of organic groups and inorganic groups. The higher the electro negativity of the biomass, the greater the attraction and adsorption of heavy metal cations. Thus, the remaining $\mathrm{H}^{+}$ions on the acidic

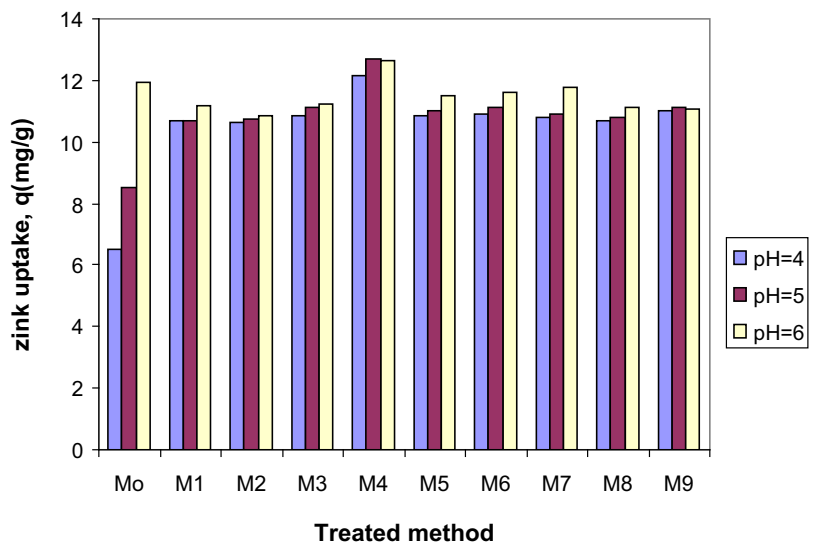

$\mathrm{NaoH}, \quad \mathrm{M}_{4}=0.1 \mathrm{~N} \quad \mathrm{NaOH}+$ autoclave, $\quad \mathrm{M}_{5}=0.2 \mathrm{~N} \quad \mathrm{Na}_{2} \mathrm{CO}_{3}$, $\mathrm{M}_{6}=0.2 \mathrm{~N} \quad \mathrm{Na}_{2} \mathrm{CO}_{3}+$ autoclave, $\quad \mathrm{M}_{7}=\mathrm{H}_{2} \mathrm{O}, \quad \mathrm{M}_{8}=125 \mathrm{~mL}$ formaldehyde and $250 \mathrm{~mL}$ formic acid, $\mathrm{M}_{9}=$ immobilized yeast

pretreated yeast biomass may change the biomass electro negativity, resulting in reduction in biosorption capacity [35]. $0.1 \mathrm{~N} \mathrm{NaOH}$ has been observed to reduce the biosorption capacity from 6.00 to $3.93 \mathrm{mg} / \mathrm{g}$ at $\mathrm{pH} 4$ and increase biosorption capacity from 7.44 to 11.26 and from 7.49 to $12.82 \mathrm{mg} / \mathrm{g}$ at $\mathrm{pH} 5$ and 6 , respectively. While using $0.1 \mathrm{~N} \mathrm{NaOH}$ with autoclaving increases biosorption 
capacity at $\mathrm{pH} 4,5$, and $6(6.00-11.79,7.44-12.22$, and $7.49-12.31 \mathrm{mg} / \mathrm{g}$ ). On the other hand, the use of $0.2 \mathrm{~N}$ $\mathrm{Na}_{2} \mathrm{CO}_{3}$ with and without autoclaving gives (6.00-6.75, $7.44-12.84$, and $7.49-13.24 \mathrm{mg} / \mathrm{g}) ; \quad(6.00-10.18$, $7.44-12.84$, and $7.49-13.20 \mathrm{mg} / \mathrm{g}$ ), respectively. It is important to mention here that the alkali treatment of biomass may destroy autolytic enzymes that cause putrification of yeast and remove lipids and proteins that mask reactive sites [36]. The same Figure shows that the pretreatment using $\mathrm{H}_{2} \mathrm{O}$ at $\mathrm{pH} 4,5$, and 6 gives $6.00-12.04,7.44-11.68$, and $7.49-13.10 \mathrm{mg} / \mathrm{g}$. The increase is attributed to the exposure of latent binding sites after the pretreatment. Pretreatment using formaldehyde and formic acid reduces biosorption capacity at $\mathrm{pH} 4(6.00-3.93 \mathrm{mg} / \mathrm{g})$, the reduction of biosorption capacity in comparison with raw yeast may be attributed to the loss of intracellular uptake at low $\mathrm{pH}$, or causes metalation process of amine groups which has great removal effect which increasing biosorption capacity at $\mathrm{pH} 5,6(7.44-11.265,7.497-12.825 \mathrm{mg} / \mathrm{g})$. In the form of immobilized yeast the results are (6.00-10.83, 7.44-11.53, and 7.49-11.63 mg/g). The higher metal uptake values may be explained by the increase in the availability of binding sites and thereby the improvement in the access of metal ions to the metal binding sites of yeast cells. The effect of caustic and heat pretreatment on lead biosorption capacity of yeast cells was determined. The highest metal uptake was obtained with these methods of pretreatment explained by the removal of protein groups of the cell wall that makes non-adsorbable protein complexes with lead ions [37]. On the other hand, when heavy metals become tightly bound to acid groups in the side chains of amino acids on the cell surface, salt linkages are broken and the proteins are dissolved from the cell wall. When protein is dissolved from the cell wall of the yeast cells, the protein molecules in the liquid phase compete for lead ions with the protein molecules on the cell wall forming non-adsorbable $\mathrm{Pb}^{+2}$-protein complexes [37, 38]. By fixing the soluble protein in the cell wall by some denaturation processes such as heat and caustic treatments, the removal capacity may be improved. Removal of surface impurities, rupture of cell membrane, and exposure of available binding sites for metal biosorption after pretreatment may be the reason for the increase in metal biosorption. The residual alkalinity in biomass may result in increased hydrolysis of certain metals and thereby enhance overall metal removal by the biomass. Besides, the pretreatment could release polymers such as polysaccharides that have a high affinity towards certain metal ions. Therefore, if $\mathrm{Pb}, \mathrm{Cd}, \mathrm{Cr}, \mathrm{Cu}, \mathrm{Co}$, and $\mathrm{Zn}$ are to be removed from aqueous solutions, the use of certain pretreatment such as alkaline chemical pretreatment may have advantages in improving removal efficiency. These results are in agreement with those of several researchers [34]. Goksungur et al. [39] stated that caustic treated yeast improved biosorption capacity of copper. Yin et al. [40] studied biosorption of copper using calcium-treated fungal biomass and found that pretreatment of the biomass with calcium solution and heat improved the stability and settling property and increased heavy metal uptake capacities. Therefore, in the present work, the amount of metal ions biosorbed by raw or pretreated yeast varied with metals and this may be related to the ionic radii of metal; the greater the covalent index value of metal ion, the greater the potential to form covalent bonds with biological ligands [41]. Other metals can be discussed in similar way. Figure 10 shows the effect of pretreated method on uptake of other five metals.

\section{Conclusion}

The uptake capacity of lead, cadmium, chrome, copper, cobalt, and zinc increases with increasing of initial metal concentration and decreases with increasing of biosorbent weight. The uptake capacity increases with increasing $\mathrm{pH}$ and the maximum capacity values have been observed at $\mathrm{pH}$ 6.0, 5.5, 2.5, 5.5, 6.0, and 5.5 for lead, cadmium, chrome, copper, cobalt, and zinc, respectively. The uptake capacities of metal ions followed the order of $\mathrm{Pb}>\mathrm{Zn}>\mathrm{Cr}>\mathrm{Co}>\mathrm{Cd}>\mathrm{Cu}$. The biosorption isotherm is well described by Langmuir and Freundlich equations. The sorption kinetics follows the pseudo-second order rate equation, which means that the external mass transfer and intraparticle diffusion together are involved in sorption process. Among the pretreatment methods which have been used to increase the biosorption capacity of the yeast, alkaline treatment was found to be superior to the others. Desorption studies conducted showed that the metal ions sorbed onto the yeast could be desorbed effectively using $0.05 \mathrm{~N}$ nitric acid and the spent yeast could be regenerated with $0.2 \mathrm{~N}$ sodium hydroxide solution. It could be reused several times indicating the high integrity and mechanical strength of the beads. Carboxyl, amine, and phosphate groups play an important role in biosorption of metal ions.

Acknowledgments The authors thank and appreciate the support of Chemical Engineering Department, University of Technology, Baghdad, Iraq and Botany Department, Faculty of Science, Almansoura University, Egypt.

Open Access This article is distributed under the terms of the Creative Commons Attribution 4.0 International License (http:// creativecommons.org/licenses/by/4.0/), which permits unrestricted use, distribution, and reproduction in any medium, provided you give appropriate credit to the original author(s) and the source, provide a link to the Creative Commons license, and indicate if changes were made. 


\section{References}

1. Wang J (2002) Immobilization techniques for biocatalysts and water pollution control. Science Press, Beijing

2. Galun M, Galun E, Siegel BZ, Keller P, Lehr H, Siegel SM (1987) Removal of metal ions from aqueous solutions by penicillium biomass: kinetic and uptake parameter. Water Air Soil Pollut 33:359-371

3. Sari A, Mustafa T (2008) Biosorption of total chromium from aqueous solution by red algae (Ceramiumvirgatum): equilibrium, kinetic and thermodynamic studies. J Hazard Mater 160:349-355

4. Mullen MD, Wolf DC, Fems FG, Beveridge TJ, Flemming CA, Bailey GW (1989) Bacterial sorption of heavy metals. Appl Environ Microbiol 54:143-3149

5. Smith JK, Vesilind PA (1995) Dilatometric measurement of bound water in wastewater sludge. Water Res 29:2621-2626

6. Kapoor A, Viraraghavan T (1995) Fungi biosorption, an alternative treatment option for heavy metal bearing wastewaters: a review. Bioresour Technol 3:195-206

7. Zhou DQ (2002) Microbiology, 2nd edn. Higher Education Press, China, Beijing

8. Eide DJ (1998) The molecular biology of metal ion transport in Saccharomyces Cerevisiae. Annu Rev Nutr 18(1998):441-469

9. Tuzen M, Sari A, Mendil D, Uluozlu OD, Soylak M, Dogan M (2009) Characterization of biosorption process of As(III) on green algae Ulothrix cylindricum. J Hazard Mater 165(1-3):566-572

10. Desi I, Nagymajtenyi L, Schulz H (1998) Behavioral and neurotoxicological changes caused by cadmium treatment of rats during development. J Appl Toxicol 18:63-70

11. Sari A, Mendil D, Mustafa T, Mustafa S (2008) Biosorption of $\mathrm{Cd}$ (II) and $\mathrm{Cr}$ (III) from aqueous solution by moss (Hylocomiumsplendens) biomass: equilibrium, kinetic and thermodynamic studies. Chem Eng J 144:1-9

12. Benguella B, Benaissa $H$ (2002) Cadmium removal from aqueous solution by chitin: kinetic and equilibrium studies. Water Res 36:2436-2440

13. Kapoor A, Viraraghavan T, Cullimore D (1999) Removal of heavy metals using fungus Aspergillus niger. Bioresour Technol 70:95-104

14. Kratochvil D, Volesky B (1998) Advanced in biosorption of heavy metals. Trends Biotechnol 16:291-300

15. Huang CP, Westman D, Quirk K, Huang JP (1988) The removal of cadmium (II) from dilute aqueous solutions by fungal adsorbent. Water Sci Technol 20:369-376

16. Hughes MN (1989) Poole RK metals and microorganisms. Chapman and Hall, London

17. Tobin JM, Cooper DG, Neufeld RJ (1984) Uptake of metal ions by rhizopus arrihizuz biomass. Appl Environ Microbiol $47: 821-824$

18. Fourest E, Roux JC (1992) Heavy metal biosorption by fungi mycelial byproducts: mechanisms and influence of $\mathrm{pH}$. Appl Microbiol Biotechnol 33:399-403

19. Ozer A, Ozer D (2003) Comparative study of the biosorption of $\mathrm{Pb}(\mathrm{II}), \mathrm{Ni}(\mathrm{II})$ and $\mathrm{Cr}(\mathrm{VI})$ ions onto $S$. cerevisiae: determination of biosorption heats. J Hazar Mater 100:219-229

20. Gundogdu A, Ozdes D, Duran C, Bulut VN, Soylak M, Senturk $\mathrm{HB}$ (2009) Biosorption of $\mathrm{Pb}$ (II) ions from aqueous solution by pine bark (Pinusbrutia Ten.). Chem Eng J 153:62-69

21. Casas A, Alvarez F, Cifuentes L (2000) Aqueous speciation of sulphuric acid-cupric sulphate solutions. Chem Eng Sci 55:6223-6234
22. Ozgür D, Sari A, Mustafa T, Mustafa S (2008) Biosorption of $\mathrm{Pb}$ (II) and $\mathrm{Cr}$ (III) from aqueous solution by lichen (Parmelinatiliaceae) biomass. Bioresour Technol 99:2972-2980

23. Sarı A, Mustafa T (2009) Kinetic and equilibrium studies of biosorption of $\mathrm{Pb}(\mathrm{II})$ and $\mathrm{Cd}(\mathrm{II})$ from aqueous solution by macrofungus (Amanita rubescens) biomass. J Hazard Mater 164:1004-1011

24. Sudhir D, Tripathi RM, Hegde AG (2007) Biosorption of lead and copper from aqueous solutions by pretreated crab and arca shell biomass. Environmental Section, Mumbai 400085, India

25. Chen C, Wang J (2007) Removal of Pb, Ag, Cs, and Sr from aqueous solution by brewery waste biomass. Tsinhua University, Beijing 10008, People's Republic of China

26. Hany H, Soha F, Kamal K (2009) Biosorption of heavy metals from waste water using Pseudomonas sp. Elctr J Biotech 7:3-9

27. Zheng Y, Fang X, Ye Z, Li Y, Cai W (2008) Biosorption of $\mathrm{Cu}(\mathrm{II})$ on extracellular polymers from Bacillus sp. J Environ Sci (China) 20:1288-1293

28. Sawalha MF, Peralta-Videa JR, Romero-González J, GardeaTorresdey JL (2006) Biosorptionof Cd(II), Cr(III), andCr(VI) by saltbush (Atriplex canescens) biomass: thermodynamic and isotherm studies. J Colloid Interface Sci 300:100-104

29. Mittal A, Kurup L, Mittal J (2007) Freundlich and Langmuir adsorption isotherms and kinetics for the removal of Tartrazine from aqueous solutions using hen feathers. J Hazard Mater 146:243-248

30. Doss VR, Kodolikar SP (2012) Heavy metal adsorption by Ligand loaded granular activated carbon: thermodynamics and kinetics. Int J Environ Sci 2:2126-2142

31. Long C, Li A, Wu H, Zhang Q (2009) Adsorption of naphthalene onto macroporous and hypercrosslinked polymeric adsorbent: effect of pore structure of adsorbents on thermodynamic and kinetic properties. Colloids Surf A: Physicochem Eng Asp 333:150-155

32. Plazinski W, Rudzinski W, Plazinska A (2009) Theoretical models of sorption kinetics including a surface reaction mechanism: a review. Adv Colloid Interface Sci 152:2-13

33. Sag Y, Aktay Y (2000) Mass transfer and equilibrium studies for the sorption of chromium ions on to chitin. Process Biochem 36:157-173

34. Bruno L, Claudio CV, Adeval S (2005) Sorption and desorption of $\mathrm{Pb}^{+2}$ ions by dead Sargassam sp. Biomass J Biochem Eng 27:310-314

35. Chihpin H, Huang CP (1996) Application of Aspergillus Oryzae and Rhisopus Oryzae for $\mathrm{Cu}$ (II) removal. Water Res 30:1985-1990

36. Atkinson BW, Bux F, Kasan HC (1996) Bioremediation of metal contaminated industrial effluents using waste sludges. Water Sci Technol 34:9-15

37. Hammaini A (2003) Simultaneous uptake of metals by activated sludge. Miner Eng 16:723-729

38. Igwe JC, Abia AA (2005) Sorption kinetic and intraparticulate diffusivities of metal ions on maize cob. J Biotech 4:509-512

39. Loaec M, Olier R, Guezennec J (1997) Uptake of lead, cadmium and zinc by a novel bacterial expolysaccharide. Water Res 31:1171-1179

40. Goksungur Y, Uren S, Guvenc U (2005) Biosorption of cadmium and lead ions by ethanol treated waste Baker's yeast. Biomass Bioresour Technol 96:103-109

41. Yin P, Quiming Y, Jin B, Ling Z (1999) Biosorption removal of cadmium from aqueous solution by pretreated fungal biomass. Water Res 338:1960-1963 